\section{Optimizing Postharvest Life of Cut 'Renaissance Red' Poinsettias}

\author{
John M. Dole \\ Department of Horticultural Science, North Carolina State University, Raleigh, \\ NC 27695-7609
}

Paul Fisher

Department of Plant Biology, University of New Hampshire, Durham, NH 03824-3597

\section{Geoffrey Njue}

University of New Hampshire Cooperative Extension Service, Durham, NH 03824-3597

Additional index words. Euphorbia pulcherrima, vase life, cut flower, 'Winter Rose', postharvest physiology

Abstract. Several treatments were investigated for increasing vase life of cut 'Renaissance Red' poinsettia (Euphorbia pulcherrima Willd. ex Klotzsch.) stems. A vase life of at least 20.6 days resulted when harvested stems were placed directly into vases with $22{ }^{\circ} \mathrm{C}$ deionized water plus $200 \mathrm{mg} \cdot \mathrm{L}^{-1} 8-\mathrm{HQS}$ (the standard floral solution used) and $0 \%$ to $1 \%$ sucrose without floral foam. Maturity of stems at harvest, ranging from 0 to 4 weeks after anthesis, had no effect on vase life or days to first abscised leaf. Pretreatments immediately after harvest using floral solution heated to 38 or $100{ }^{\circ} \mathrm{C}$, or 1 or 10 -min dips in isopropyl alcohol, had no effect, whereas 24 hours in $10 \%$ sucrose shortened vase life by 6.4 days and time to first abscised cyathium by 4.5 days. Stem storage at $10^{\circ} \mathrm{C}$ decreased vase life, particularly when stems were stored dry (with only 0.8 days vase life after 3 weeks dry storage). Increasing duration of wet storage in floral solution from 0 to 3 weeks decreased vase life from 21.5 to 14.6 days. Placing cut stems in a vase containing floral foam decreased time to first abscised leaf by 3.7 to 11.6 days compared with no foam. A $1 \%$ to $2 \%$ sucrose concentration in the vase solution produced the longest postharvest life for stems placed in foam but had little effect on stems not placed in foam. A 4\% sucrose concentration decreased vase life compared with lower sucrose concentrations regardless of the presence of foam. Holding stems in the standard floral solution increased vase life and delayed leaf abscission compared with deionized or tap water only, with further improvement when stem bases were recut every three days. Commercial floral pretreatments and holding solutions had no effect on vase life and days to first abscised cyathium but delayed leaf abscission.
(Gordon et al., 1986; Leonard et al., 2000). Poinsettias produce a milky latex when cut and several pretreatments have been proposed to eliminate potential stem-plugging from the latex, including dipping the stem ends in alcohol or boiling water and heat searing. Gordon et al. (1986) noted that 10-min dips in isopropyl alcohol applied immediately or within an hour after harvest increased vase life of cut poinsettias by 3.0 d. Holstead (1993) recommended placing cut stems of cultivars that produce a lot of latex (sap) when cut into plain water for one hour followed by $10 \mathrm{~min}$ dips in isopropyl alcohol.P. Fisher (unpublished data) also noted that vase life increased by $5.5 \mathrm{~d}$ when stems were dipped for $10 \mathrm{~min}$ in isopropyl alcohol and by $3.3 \mathrm{~d}$ for stems dipped for $10 \mathrm{~min}$ in $70^{\circ} \mathrm{C}$ water compared with the distilled water control. Both dip treatments stopped latex flow. In addition, other pretreatments such as heated water (about $38^{\circ} \mathrm{C}$ ) to enhance water absorption and high concentrations of sucrose, ranging from $0.5 \%$ to $25 \%$, have increased the vase life of other cut flower species (Goszczynska and Rudnicki, 1988; Nowak and Rudnicki, 1990; Serek et al., 1995).

Potted poinsettias are sensitive to ethylene and ethylene evolution increases after plants have been mechanically stressed by sleeving (Sacalis, 1978; Saltveit and Larson, 1981; 1983; Saltveit et al., 1979). Silver nitrate reduced ethylene-induced epinasty (Saltveit et al., 1979), indicating that anti-ethylene agents may be beneficial to cut poinsettias.

Cut stems might also benefit from a continuous supply of sucrose in the vase solution (Halevy and Mayak, 1979; Sacalis, 1993). With the presence of sucrose, addition of a germicide, such as 8-hydroxyquinoline citrate (8-HQC) or 8-hydroxyquinoline sulfate (8-HQS), is necessary to inhibit microbial growth (Halevy and Mayak, 1981; Sacalis, 1993). Gordon et
Novel cut flowers are increasingly important to provide profitable crops for North American cut flower growers, because of international competition with traditional high-volume cut flowers (Jerardo, 2002). To enhance future growth in specialty cut flowers, postharvest research on new cut flowers is needed to ensure proper handling by the grower, wholesaler, florist, and consumer.

New breeding efforts with the popular 'Winter Rose' potted poinsettia (Paul Ecke Ranch, Encinitas, Calif.) have resulted in several colors of cut flower varieties in the 'Renaissance' series (Fig. 1). The large, striking flowers are carried on long, strong stems, making them easy to use by the floral industry and the general public (Dole and Aufill, 2000).

Limited research, however, has examined the postharvest life of cut poinsettia flowers

Received for publication 13 Jan. 2003. Accepted for publication 8 Mar. 2004. We would like to extend special thanks to the Fred C. GloecknerFoundation for supporting this research and to the Paul Ecke Ranch for providing the poinsettia cuttings. We also thank Ingram McCall and Diane Mays for data collection and Beth Harden, Frankie Fanelli, and Lane Greer for assistance with setting up the experiments.

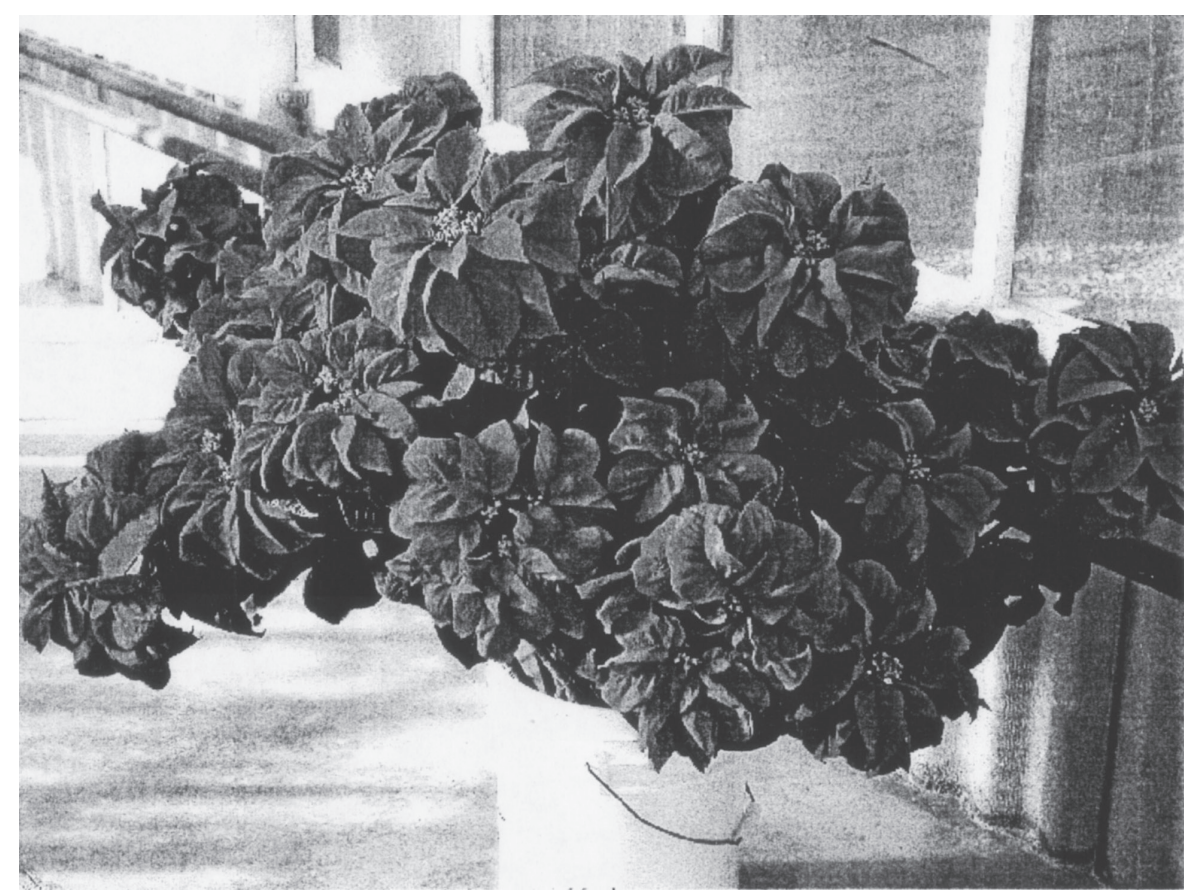

Fig. 1. Cut 'Renaissance Red' poinsettias. Note the long stems and large, up to $23 \mathrm{~cm}$ wide, inflorescences with curled red bracts. 
al. (1986), however, did not find commercial preservatives (Floralife, Floralife, Walterboro, S.C.) to be useful with cut poinsettias.

Additional improvement in stem life could result from harvesting at the optimal stage of flower development. Flowers harvested for direct sale, as often occurs with specialty cut flowers, can be cut at more advanced stages than flowers shipped long distances (Halevy and Mayak, 1979; Sacalis, 1993).

Cold storage of stems benefits the grower and florist by extending the season, regulating availability during peak production or high demand periods, improving production efficiency, and enabling long-term shipment (Goszczynska and Rudnicki, 1988). Recommended storage temperatures for cut flowers depend on the particular species and cultivar, but generally vary between 0 and $4{ }^{\circ} \mathrm{C}$ (Nowak and Rudnicki, 1990). However, Staby et al. (1978) noted that the optimum storage temperature for sleeved potted poinsettia plants was $10^{\circ} \mathrm{C}$; plants stored at 2 to $7^{\circ} \mathrm{C}$ exhibited chilling damage while plants stored at 13 to $16^{\circ} \mathrm{C}$ showed leaf petiole epinasty and bract drooping due to ethylene production.

The objectives of this project were to maximize the storage and vase life of Euphorbia pulcherrima 'Renaissance Red', examining harvest stage, floral solutions, pretreatments, cold storage duration, and vase substrates.

\section{Materials and Methods}

Plant materials. Euphorbia pulcherrima 'Renaissance Red' plants were planted on 1 Aug. with 2 plants per 20-cm-diameter pot, pinched 2 weeks later, and grown under natural day lengths at $27^{\circ} \mathrm{C}$ day (setpoint) and 19 ${ }^{\circ} \mathrm{C}$ night until 25 Sept., followed by $21 / 19{ }^{\circ} \mathrm{C}$ day/night until anthesis. Plants were grown in a double polyethylene-covered greenhouse in Raleigh, N.C., and irrigated with $225 \mathrm{mg} \cdot \mathrm{L}^{-1} \mathrm{~N}$ from Peters 20-4.4-16.6 PLS (The Scott's Co., Marysville, Ohio) until 29 Oct. and $200 \mathrm{mg} \cdot \mathrm{L}^{-1}$ N until harvest, except on weekends when clear water was applied.

Harvest procedures. Cut stems were harvested when one or two cyathia had anthers visible (anthesis), unless otherwise indicated. Stems were harvested and placed immediately into unamended tap water $[\mathrm{pH} 6.1$, electrical conductivity (EC) $\left.0.21 \mathrm{dS} \cdot \mathrm{m}^{-1}\right]$ until trimmed to $30 \mathrm{~cm}$ and placed in the appropriate treatment. After trimming, the control solution (floral solution, $\mathrm{pH} 3.5$, EC $0.29 \mathrm{dS} \cdot \mathrm{m}^{-1}$ ) used in all experiments was $22 \pm 1{ }^{\circ} \mathrm{C}$ deionized water amended with $200 \mathrm{mg} \cdot \mathrm{L}^{-1} 8$-hydroxyquinoline sulfate (8-HQS). Room air temperature was set at $20 / 22^{\circ} \mathrm{Cminimum} /$ maximum, light level was a minimum of $50 \mu \mathrm{mol} \cdot \mathrm{m}^{-2} \cdot \mathrm{s}^{-1}$ for $12 \mathrm{~h}$, and relative humidity was $40 \%$ to $60 \%$. The following data were measured in each experiment: vase life after removal from treatment and days to the first abscised leaf and first abscised cyathium. Stems were terminated when bracts were wilted or $>10 \%$ discolored or when the stem collapsed (bent neck). Vase solutions were replenished as needed by adding to the existing solution. Each of the following experiments was a completely randomized design.
Harvest stage. Fifteen replicate cut stems were harvested at three stages of development: 1) one to two cyathia with anthers visible (anthesis), 2) 2 weeks after anthesis, and 3) 4 weeks after anthesis. After harvest, stems were placed directly into glass vases filled with floral solution.

Pretreatments. Fifteen replicate cut stems received seven different pretreatments: 1 ) floral solution initially heated to $\left.38 \pm 0.5^{\circ} \mathrm{C}, 2\right) 4-\mathrm{h}$ $0.5 \mathrm{mg} \cdot \mathrm{L}^{-1}$ 1-methylcyclopropene (1-MCP) treatment (EthylBloc, BioTechnologies for Horticulture, Inc., Burr Ridge, Ill.) and 22 $\pm 1{ }^{\circ} \mathrm{C}$ floral solution, 3) 1 -min dip in $70 \%$ isopropyl alcohol followed by placement in 22 $\pm 1^{\circ} \mathrm{C}$ floral solution, 4) same as (3) except a 10-min dip was used, 5) 10-min dip in boiling water followed by placement in $22 \pm 1^{\circ} \mathrm{C}$ floral solution, 6) $24 \mathrm{~h}$ in $10 \%$ sucrose in $22 \pm 1{ }^{\circ} \mathrm{C}$ floral solution followed by placement in $22 \pm$ $1{ }^{\circ} \mathrm{C}$ floral solution, or 7) no pretreatment and $22 \pm 1{ }^{\circ} \mathrm{C}$ floral solution.

Cold storage duration. Ten replicate cut stems were held $0,1,2$, or 3 weeks in a $10^{\circ} \mathrm{C}$ cooler (RH $80 \%$ to $90 \%$ ) either dry or wet. For dry storage, stems were placed in boxes lined with paper and black plastic. Wet stems were placed in sterile plastic buckets filled with floral solution. The 0 week storage stems were placed directly into vases filled with floral solution. After 1,2, and 3 weeks, ten stems were randomly selected from each treatment, recut (removing $1.3 \mathrm{~cm}$ ) under water, and placed in vases filled with floral solution. All remaining stems held in floral solution were recut and placed back into their respective treatments.

Vase sucrose concentration and substrates. Ten replicate cut stems were placed in vases containing floral solution and $0 \%, 0.5 \%, 1 \%$, $2 \%$, or $4 \%$ sucrose, in a factorial design with or without floral foam (Aquafoam Instant, Syndicate Sales, Inc., Kokomo, Ind.). Foam was thoroughly soaked in the respective solution before placement in vase.

Evaluation of standard floral solution. The standard vase solution in these trials was deionized water plus $200 \mathrm{mg} \cdot \mathrm{L}^{-1} 8-\mathrm{HQS}$. We compared vase life of 15 replicate cut stems placed into the standard vase solution against three other vase conditions, all at $22 \pm 1{ }^{\circ} \mathrm{C}$ : 1) unamended tap water, 2) deionized water $\left(\mathrm{pH} 4.6, \mathrm{EC} 0 \mathrm{dS} \cdot \mathrm{m}^{-1}\right)$, or 3 ) the standard vase solution plus recutting, removing $1.3 \mathrm{~cm}$ of stem every third day.

Table 1. Effect of heated floral solution, ethanol dip, and $10 \%$ sucrose pretreatments on vase life and days to first cyathium abscission of cut 'Renaissance Red' poinsettia stems.

\begin{tabular}{lcc}
\hline Pretreatment & $\begin{array}{c}\text { Vase } \\
\text { life } \\
\text { (d) }\end{array}$ & $\begin{array}{c}\text { Days to 1st } \\
\text { cyathium } \\
\text { abscission }\end{array}$ \\
\hline Floral solution at $22^{\circ} \mathrm{C}$ & $20.6 \mathrm{a} \mathrm{a}^{\mathrm{z}, \mathrm{y}}$ & $17.5 \mathrm{~b}$ \\
Floral solution at $38^{\circ} \mathrm{C}$ & $23.7 \mathrm{a}$ & $17.6 \mathrm{~b}$ \\
Floral solution for 10 -min at $100{ }^{\circ} \mathrm{C}$ & $22.3 \mathrm{a}$ & $17.4 \mathrm{~b}$ \\
Isopropyl dip $(70 \%)$ for $1 \mathrm{~min}$ & $23.9 \mathrm{a}$ & $18.4 \mathrm{ab}$ \\
Isopropyl dip $(70 \%)$ for $10 \mathrm{~min}$ & $23.9 \mathrm{a}$ & $19.7 \mathrm{a}$ \\
Sucrose $(10 \%)$ & $14.2 \mathrm{~b}$ & $13.0 \mathrm{c}$ \\
Significance & $* *$ & $*$ \\
\hline
\end{tabular}

${ }^{2}$ Means are an average of 15 replicate stems.

${ }^{y}$ Means within a column followed by the same letter are not significantly different at $P \leq 0.05$ as determined by Duncan's multiple range test.

${ }^{*, * *}$ Significant at 0.05 or 0.01 levels, respectively.
Commercial preservative. Fifteen replicate cut stems were treated with one of two hydration solutions used according to manufacturer's directions: 1 s in Floralife Quick Dip (Floralife, Walterboro, S.C.) or 4h in Chrysal Professional Hydrating Solution (Pokon \& Chrysal, Miami, Fla.). Control stems were held at $4 \mathrm{~h}$ in $22 \pm$ $1{ }^{\circ} \mathrm{C}$ floral solution. After pretreatment stems were placed in one of two holding solutions used according to manufacturer's directions: Floralife Clear Professional Flower Food or Chrysal Clear Professional 2 Processing Solution. Control stems were placed in $22 \pm 1{ }^{\circ} \mathrm{C}$ floral solution.

Statistical procedures. All data were analyzed using the general linear model procedure in SAS (SAS Institute, Cary, N.C.). Data in harvest stage, pretreatment, control solution evaluation and commercial preservative experiments were transformed using the $\log _{10}$ procedure and were analyzed with the ANOVA procedure using Duncan's multiple range test for mean separation. For the cold storage experiment, storage condition (dry or wet) was analyzed using the general linear model procedure as a discrete variable, with linear and quadratic terms for storage duration, and an interaction term between storage vase sucrose concentration and substrates experiment, substrate type (with or without foam) was analyzed using the general linear model as a discrete variable, with linear and quadratic terms for sucrose concentration, and an interaction term between substrate and sucrose concentration (linear term).

\section{Results and Discussion}

Harvest stage. Delaying harvest from 0 to 2 or 4 weeks after anthesis resulted in fewer cyathia on the stems (data not presented), thus linearly decreasing the number of cyathia that abscised after harvest from 15.4 to 8.1 or 0 , respectively. Harvest maturity had no effect on vase life or days to first leaf abscission (data not presented). Because cyathia are normally a beneficial aesthetic feature of the poinsettia inflorescence indicating freshness, harvest near anthesis date would be preferable to provide the best initial presentation. If presence of cyathia was not essential, however, producers could cut stems from the same stand over a several week period. conditions and duration (linear term). In the 


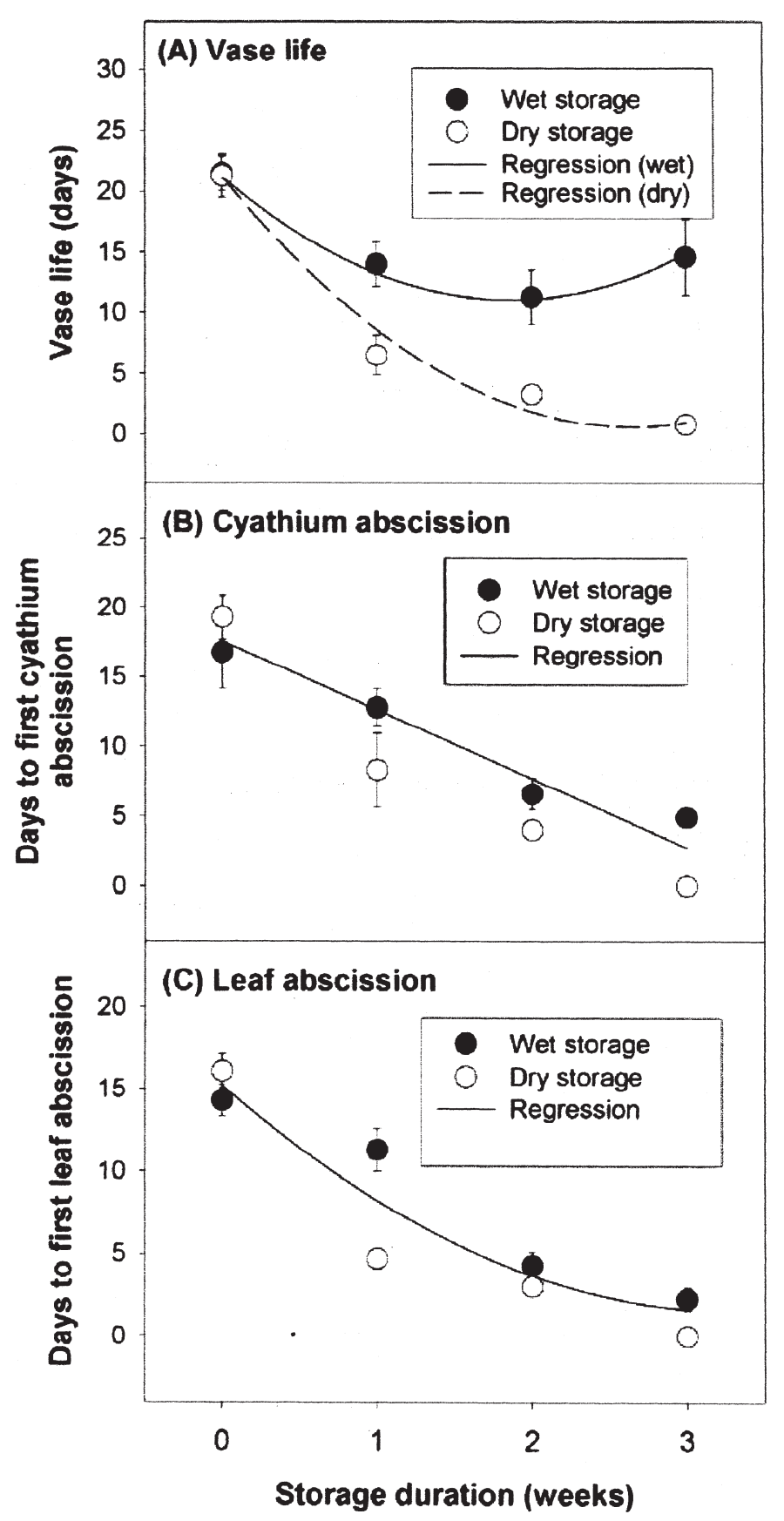

Fig. 2. Effect of $0,1,2$, or 3 weeks $10{ }^{\circ} \mathrm{C}$ storage (duration) in wet and dry conditions (handling) on cut stem vase life (A) and days to first postharvest cyathium $(\mathbf{B})$ or leaf $(\mathbf{C})$ abscission. Only statistically significant terms $(P<0.05)$ were included in the regression curves shown, where handling was analyzed as a discrete class variable, and duration was analyzed as a continuous variable with linear and quadratic terms. Linear and quadratic terms for storage duration, and the interaction of handling $x$ duration significantly affected vase life (A). Days to first cyathium abscission decreased linearly with increasing storage duration, but no other effects were significant (B). Days to first leaf abscission also decreased with increasing storage duration, and linear and quadratic terms for duration were significant $(\mathbf{C})$. Symbols represent means from 10 replicate stems \pm standard error.

Pretreatments. Pretreatments did not increase vase life or delay leaf abscission (Table 1980).
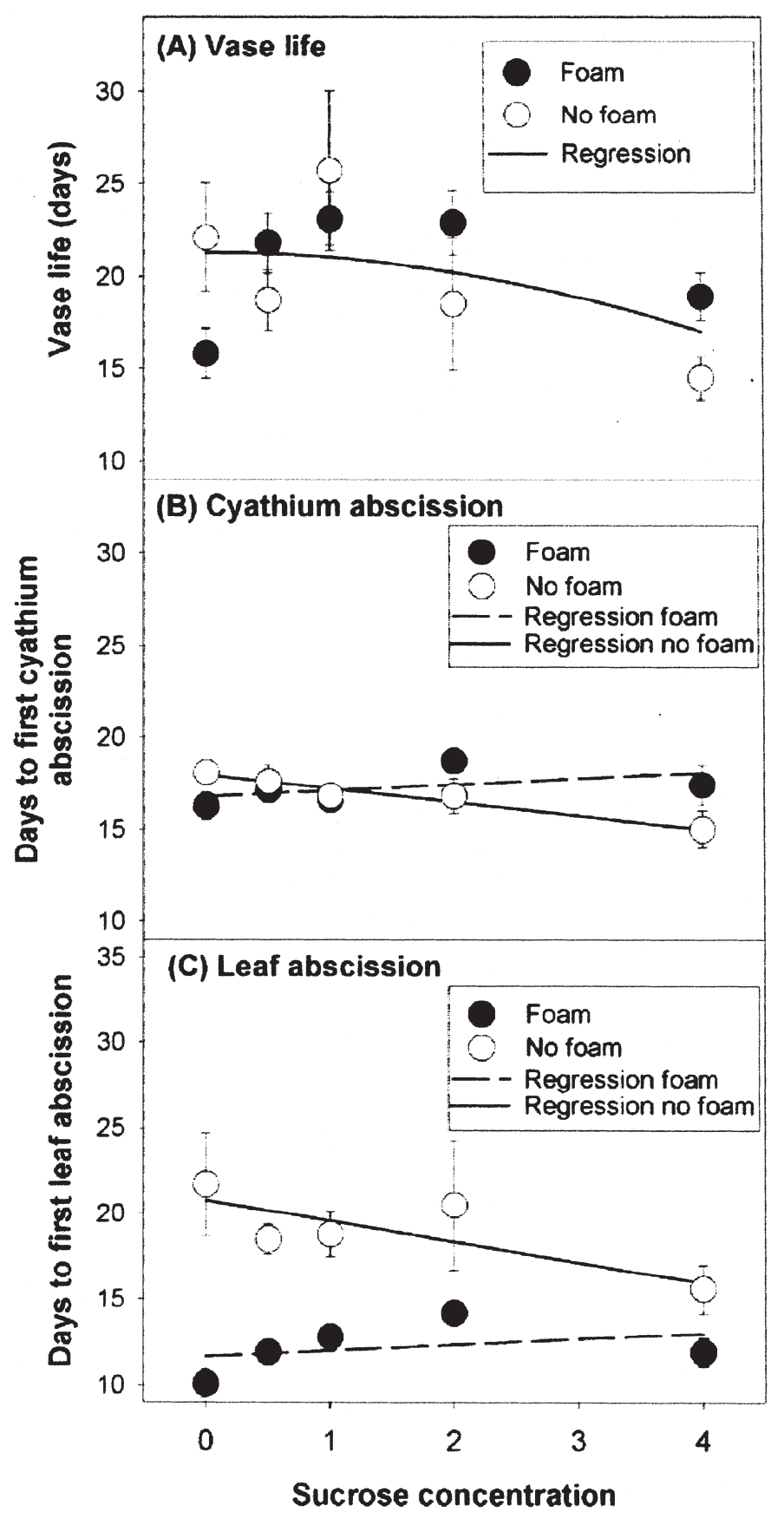

1). Floral solution heated to 38 or $100{ }^{\circ} \mathrm{C}(10$ $\mathrm{min}$ ) had no effect on vase life or days to first cyathium abscission. Leonard et al. (2000) also noted that $100^{\circ} \mathrm{C}$ water dips had no effect. In contrast, a $24-\mathrm{h}$ pulse of $10 \%$ sucrose reduced vase life and resulted in the earliest cyathium abscission (13.0 d). Although low endogenous carbohydrate level resulting from low light during production reportedly promoted cyathium abscission in potted poinsettias (Miller and Heins, 1986), the 10\% sucrose pulse hastened cyathium abscission in cut poinsettias. The sucrose concentration might have been too high, as noted for other cut flowers, such as Dendranthema (DC.) Desmoul. and Rosa L. (Halevy et al., 1978; Kofranek and Halevy,

The lack of response by cut poinsettias to 1-MCP (data not presented) may be due to cultivar variation. Saltveit et al. (1979) noted
Fig. 3. Effect of floral foam or water vase substrate (substrate) and $0,0.5,1.0,2.0$ or $4.0 \%$ sucrose (sucrose) in the vase floral solution on cut stem vase life (A), and days to first postharvest cyathium (B) or leaf (C) abscission. Only statistically significant terms $(P<0.05)$ were included in the regression curves shown, where substrate was analyzed as a discrete class variable, and sucrose concentration was analyzed as a continuous variable with linear and quadratic terms. For vase life (A), the quadratic sucrose term was statistically significant, but there was no effect of substrate. Substrate and the interaction of sucrose and substrate affected cyathium abscission (B) and leaf abscission $(\mathbf{C})$. Symbols represent means from 10 replicate stems \pm standard error.

that 'Eckespoint C-1 Red' and 'V-14' were less sensitive than 'Annette Hegg Diva' to external ethylene and endogenous ethylene induced by sleeving. 'Renaissance Red' is closely related to the potted poinsettia cultivar 'Winter Rose 
Red' which may not be ethylene sensitive as it has a long postharvest life and handles the rigors of shipping well (Nell, 2003).

The 10-min isopropyl alcohol dip delayed cyathium abscission by $2.2 \mathrm{~d}$ compared with the $22^{\circ} \mathrm{C}$ floral solution control, but had no effect on vase life (Table 1). The 1-min alcohol dip had no effect on any measured data and might have been too brief to be effective. Holdstead (1993) recommended 10 min isopropyl alcohol dips only for cultivars that produce a lot of latex after harvest. The stem ends of 'Renaissance Red' poinsettias were quite woody and produced little latex when harvested. Leonard et al. (2000) concurred, noting that cut 'Winter Rose Dark Red' stems produced little latex and that 10-min 95\% ethanol dips caused faster wilting. In contrast, Gordon et al. (1986) found that 10-min dips in isopropyl alcohol applied immediately or within $1 \mathrm{~h}$ after harvest increased the time to $50 \%$ cyathium abscission in cut 'Annette Hegg Diva' and 'Annette Hegg Topwhite' poinsettias by $3 \mathrm{~d}$. However, whereas Gordon et al. (1986) defined vase life as days to $50 \%$ cyathium abscission, we differentiated between cyathium abscission and termination of vase life. Thus, while alcohol dips delayed cyathium abscission, lengthening the period the cut stems would be marketable by a wholesaler, the dips had no effect on overall vase life of 'Renaissance Red' and are not recommended.

Cold storage duration. Increasing duration of wet storage in floral solution from 0 to 1 week decreased vase life of flowers by $7.5 \mathrm{~d}$; however, longer storage had little effect on vase life (Fig. 2a). Increasing storage duration decreased vase life of flowers stored dry, such that many of the flowers were unacceptable after 3 weeks storage due to bract discoloration and those that were acceptable were terminated shortly after placement in the post-treatment environment. Flowers stored dry for 1 week had a vase life of only $6.5 \mathrm{~d}$ whereas those stored in floral solution had a vase life of 14 d. Regardless of storage conditions, increasing duration of storage decreased time to first cyathium abscission (Fig. 2b), whereas dry storage caused the most rapid leaf abscission (Fig 2c). Leonard et al. (2000) stated that leaves and bracts of cut poinsettias dry stored for $2 \mathrm{~d}$ rehydrated within 12 to $24 \mathrm{~h}$ but leaf abscission occurred.

Flower species vary in their tolerance of wet versus dry storage. For example, Campanula medium L. (Bosma and Dole, 2002) and Alstroemeria $\mathrm{L}$. hybrids tolerated wet storage better than dry storage (Dai and Paull, 1991). The warm storage temperature $\left(10^{\circ} \mathrm{C}\right)$ required for cut poinsettias might have reduced the effectiveness of dry storage, because numerous species, such as Rosa hybrids, tolerate dry and wet storage equally well at temperatures less than $10^{\circ} \mathrm{C}$ but not at higher storage temperatures due to dehydration (Cevallos and Reid, 2001).

Although vase life decreased with wet storage, the average vase life for flowers stored 1 , 2 , or 3 weeks was $13.3 \mathrm{~d}$ after removal from storage. Thus, the vase life of cut poinsettias after wet storage was similar to or longer than the expected vase life of unstored stems of many other species, for example, $10.4 \mathrm{~d}$ for Campanula medium (Bosma and Dole, 2002), 7.1 d for Eustoma grandiflora (Raf.) Shinn. (Huang and Chen, 2002), $6.3 \mathrm{~d}$ for Heuchera sanguinea Engelm. (Han, 1998), $13.2 \mathrm{~d}$ for Matthiola incana (L.) R. Br. (Çelikel and Reid, 2002), and 9.3 d for Rosa hybrids (Ohkawa et al., 1999).

The storage temperature used for this work was $10{ }^{\circ} \mathrm{C}$, much higher than the 0 to $4{ }^{\circ} \mathrm{C}$ temperature of typical commercial wholesale and retail coolers. In a preliminary experiment cut poinsettia stems showed extensive cold damage when stored at $4{ }^{\circ} \mathrm{C}$ for 1 week (data unpublished). Leonard et al. (2000) also noted that chilling injury occurred when cut stems were transported at $4{ }^{\circ} \mathrm{C}$. Staby et al. (1978) recommended a minimum storage temperature of $10^{\circ} \mathrm{C}$ for potted poinsettias to avoid chilling injury. Unfortunately, cut poinsettias would need to be stored separately from most other cut flowers other than tropical flowers, such as Anthurium Schott., Cattleya Lindl., and Heliconia L., which are typically stored at 13 to $15^{\circ} \mathrm{C}$ (Sacalis, 1993). However, high quality cut poinsettia production is not compatible with tropical cut flower production. Night temperatures above $21{ }^{\circ} \mathrm{C}$ delay poinsettia flower initiation and high humidity promotes Botrytis infection (Dole and Wilkins, 1999). While poinsettia production is compatible with Rosa and Dendranthema production, the chilling sensitivity of cut poinsettia stems prevents distribution with these cut flower species which are best shipped at 0 to $4{ }^{\circ} \mathrm{C}$ (Sacalis, 1993).
Species shipped at 0 to $4{ }^{\circ} \mathrm{C}$ make up most cut flower sales (Jerardo, 2003). Thus, while most wholesalers and retailers have cold and warm storage areas, production facilities for tropical crops are typically segregated from other crops due to climate, necessitating separate distribution. This special handling would increase the cost of cut poinsettia stems and might limit their importation or distribution through wholesale flower distributors. However, Staby et al. (1978) noted that potted poinsettias could be stored successfully at $7.2^{\circ} \mathrm{C}$ for durations of $2 \mathrm{~d}$ or less and Gordon et al. (1986) stored cut poinsettias at $4{ }^{\circ} \mathrm{C}$ for $24 \mathrm{~h}$ with no detrimental effect on vase life.

Vase sucrose concentration and substrates. The optimum sucrose concentration varied depending on whether stems were held with or without foam in the vase. Adding sucrose up to $2 \%$ concentration benefited vase life, leaf retention, and cyathium retention for stems held in foam (Fig. 3). While cut poinsettia stems can be used by florists in arrangements without leaves or cyathia, their presence is an indication of freshness. Increasing days to first leaf or cyathium abscission lengthens the time a cut stem may be marketable by a wholesaler. However, $0 \%$ to $2 \%$ sucrose had little effect on stems without foam. Increasing sucrose concentration from $2 \%$ to $4 \%$ decreased vase life and leaf retention regardless of substrate (Fig. 3). In comparison, Han (1998) found that cut Heuchera sanguinea Engelm. flowers had a longer vase life and higher percentages of opening buds at $0.5 \%$ or $1 \%$ sucrose compared to no sucrose, but stem collapse increased at

Table 2. Effect of vase solutions on vase life and days to first leaf abscission for cut 'Renaissance Red' poinsettia stems.

\begin{tabular}{lcc}
\hline & $\begin{array}{c}\text { Vase } \\
\text { life } \\
\text { Treatment }\end{array}$ & $\begin{array}{c}\text { Days to } \\
\text { 1st leaf } \\
\text { abscission }\end{array}$ \\
\hline Unamended tap water & $21.1 \mathrm{~b}^{\mathrm{z}, \mathrm{y}}$ & $13.5 \mathrm{c}$ \\
Deionized water & $16.2 \mathrm{~b}$ & $11.1 \mathrm{~d}$ \\
Deionized water $+200 \mathrm{mg} \cdot \mathrm{L}^{-1}$ 8-HQS & $28.0 \mathrm{ab}$ & $19.1 \mathrm{~b}$ \\
Deionized water $+200 \mathrm{mg} \cdot \mathrm{L}^{-1}$ 8-HQS+ recut every 3 d & $30.6 \mathrm{a}$ & $24.2 \mathrm{a}$ \\
Significance & $*$ & $* * *$ \\
\hline
\end{tabular}

${ }^{\mathrm{z}}$ Means are an average of 15 replicate stems.

${ }^{y}$ Means within a column followed by the same letter are not significantly different at $P \leq 0.05$ as determined by Duncan's multiple range test.

×8-HQS = 8-hydroxyquinoline sulfate

***** Significant at the 0.05 or 0.001 level, respectively.

Table 3. Effect of commercial pretreatments and holding solutions on days to first leaf abscission of cut 'Renaissance Red' poinsettia stems.

\begin{tabular}{lcc}
\hline $\begin{array}{l}\text { Pretreatment } \\
\text { solution }\end{array}$ & Holding & Days to 1st \\
Floralife & Folution & leaf abscission \\
& Chrysal & $24.5^{* * z y}$ \\
& Floral solution & $20.2^{\mathrm{Ns}}$ \\
Chrysal & Floralife & $17.3^{\mathrm{NS}}$ \\
& Chrysal & $17.8^{\mathrm{NS}}$ \\
& Floral solution & $24.8^{* *}$ \\
Floral solution & Floralife & $16.8^{\mathrm{NS}}$ \\
& Chrysal & $20.8^{* *}$ \\
Significance & Floral solution & $15.5^{\mathrm{NS}}$ \\
Pretreatment $(\mathrm{P})$ & & $14.3(\mathrm{control})$ \\
Holding $(\mathrm{H})$ & & $\mathrm{NS}$ \\
$\mathrm{P} \times \mathrm{H}$ & & $*$ \\
\hline
\end{tabular}

${ }^{\mathrm{z}}$ Means are an average of 15 replicate stems.

y Treatment mean compared to flowers receiving only floral solution.

NS, ${ }^{*}$ Nonsignificant or significant at the 0.05 level, respectively. 
$>1 \%$ sucrose. Cut Triteleia laxa Benth. stems had a vase life of $12 \mathrm{~d}$ when held in solutions containing $2 \%$ sucrose in water, but vase life also decreased in this species as sucrose concentration increased (Han et al., 1990).

The presence of foam in the vase hastened leaf abscission compared to no foam (Fig. 3). Unfortunately, the increase in leaf retention due to the addition of sucrose was insufficient to offset the increase in leaf abscission due to the foam vase substrate. The increased leaf abscission of stems placed in the foam might have resulted from restricted water uptake.

Evaluation of standard floral solution. The standard floral solution (deionized water plus 8-HQS) improved leaf retention compared with deionized water alone (Table 2). Leaf retention and vase life was further enhanced by recutting stems every $3 \mathrm{~d}$. Recutting probably delayed senescence by increasing water uptake. The shortest vase life and earliest leaf abscission occurred when stems were held in deionized water without $8-\mathrm{HQS}$, which is not surprising because numerous cut flower species benefit from the use of an anti-microbial agent in the vase solution (Han et al., 1990; Jones and Hill, 1993). Deionized water, 8-HQS, or recutting stems had no effect on days to cyathium abscission (data not presented).

Commercial preservatives. Commercial floral preservatives had no effect on vase life or days to first cyathium abscised (data not presented). Gordon et al. (1986) also noted that commercial preservatives had no effect on cut poinsettia vase life, but stated that the presence of preservatives would not be detrimental either. In constrast, Leonard (2000) stated that holding stems in floral preservatives decreased vase life. Holding solutions are intended to be used during storage of cut flowers after pretreatments have been used and before receipt by the final consumer.

However, three combinations of commercial floral pretreatments and holding solutions significantly delayed leaf abscission compared to the floral solution-only treatment: 1) Floralife pretreatment and holding solutions, 2) Chrysal pretreatment and holding solutions, and 3) floral solution and Floralife holding solution (Table $3)$. The longest delay in leaf abscission (24.8 d), increasing the period that cut stems would be marketable by a wholesaler, was obtained with the Chrysal pretreatment and holding solution. Considering that $0.5 \%$ to $2 \%$ sucrose had little effect on cut poinsettias, the delay in leaf abscission from commercial preservatives was probably due to the antimicrobial agents found in commercial preservatives. The commercial hydration and holding preservatives either have no sucrose or have $<1 \%$ sucrose (G. Smith, personal communication).

\section{Conclusions}

The vase life of cut 'Renaissance Red' poinsettia stems was at least $20.6 \mathrm{~d}$ when harvested with 1 or 2 cyathia showing anthers and placed directly into $22^{\circ} \mathrm{C}$ deionized water plus 200 $\mathrm{mg} \cdot \mathrm{L}^{-1} 8$-HQS (Tables 1 and 2, Figs. 2 and 3). Cut stems could be harvested up to 4 weeks after anthesis with no decrease in postharvest life, minimizing the need to cold-store stems if too many stems were available for harvest at once. Pretreatments with heated floral solution, alcohol dips, or $10 \%$ sucrose either had no effect or were detrimental. Cut stems could be stored wet at $10^{\circ} \mathrm{C}$ for 1 week but storage reduced vase life. Cut stems should not be stored dry at $10^{\circ} \mathrm{C}$. The optimum sucrose concentration was $1 \%$ to $2 \%$ for stems held in foam. 8-HQS increased vase life and delayed leaf abscission, compared with placing stems in deionized or tap water only. Recutting stems every $3 \mathrm{~d}$ further increased vase life. Commercial floral pretreatments and holding solutions delayed leaf abscission, allowing stems to be marketable by a wholesaler longer, but had no other effect.

\section{Literature Cited}

Bosma, T. and J.M. Dole. 2002. Postharvest handling of cut Campanula medium flowers. HortScience 37:954-958.

Çelikel, F.G. and M.S. Reid. 2002. Postharvest handling of stock (Matthiola incana). HortScience 37:144-147.

Cevallos, J.-C. and M.S. Reid. 2001. Effect of dry and wet storage at different temperatures on the vase life of cut flowers. HortTechnology 11:199-202.

Dai, J.W. and R.E. Paull. 1991. Postharvest handling of Alstroemeria. HortScience 26:314.

Dole, J.M. and L. Aufill. 2000. The return of cut poinsettias. GrowerTalks 64(2): 66, 68, 69.

Dole, J.M. and H.F. Wilkins. 1999. Euphorbia, p. 331-347. In. Floriculture principles and species. Prentice Hall, Upper Saddle River, N.J.

Gordon, J., K. Evensen, and E.J. Holcomb. 1986. Alcohol pretreatment of cut poinsettias. HortScience 21:1232-1233.

Goszczynska, D.M. and R.M. Rudnicki. 1988. Storage of cut flowers, p. 35-62. In: J. Janick (ed.). Horticultural reviews. vol. 10. AVI Publ. Co., Inc., Westport, Conn.

Halevy, A.H. and S. Mayak. 1979. Senescence and postharvest physiology of cut flowers, $\mathrm{p}$. 204-236. Part I. In: J. Janick (ed.). Horticultural reviews. vol. 1. AVI Publ. Co., Inc., Westport, Conn.

Halevy, A.H. and S. Mayak. 1981. Senescence and postharvest physiology of cut flowers, $\mathrm{p}$. 59-1443. Part II. In: J. Janick (ed.). Horticultural reviews. vol. 3. AVI Publ. Co., Inc., Westport, Conn.

Halevy, A.H., T.G. Byrne, R.E. Hardenburg, A.M. Kofranek, D.S. Farnham, and J.F. Thompson. 1978. Evaluation of postharvest handling meth- ods for transcontinental truck shipments of cut carnations, chrysanthemums, and roses. J.Amer. Soc. Hort. Sci. 103:151-155.

Han, S.S., A.H. Halevy, and M.S. Reid. 1990 Postharvest handling of brodiaea flowers. HortScience 25:1268-1270.

Han, S.S. 1998. Postharvest handling of cut $\mathrm{Heu}$ chera sanguinea Engelm. flowers: Effects of sucrose and silver thiosulfate. HortScience 33:731-733.

Holstead, C. 1993. Poinsettias. Florists' Rev. 184(13):32.

Huang, K.L. and W.-S. Chen. 2002. BA and sucrose increase vase life of cut Eustoma flowers. HortScience 37:547-549.

Jerardo, A. 2003. Floriculture and nursery crops situation and outlook yearbook. Market and Trade Econ. Div., Econ. Res. Serv., FLO-2003 (June).

Jones, R.B. and M. Hill. 1993. The effect of germicides on the longevity of cut flowers. J. Amer. Soc. Hort. Sci. 118:350-354.

Kofranek, A.M. and A.H. Halevy. 1980. Chemical pretreatment of chrysanthemums before shipment. Acta Hort. 113:89-95.

Leonard, R.T., T.A. Nell, J.E. Barrett, and D.G. Clark. 2000. Postharvest care and handling practices for cut poinsettia cv. 'Winter Rose Dark Red'. HortScience 35:480.

Miller, S.H. and R.D. Heins. 1986. Factors influencing premature cyathia abscission in poinsettia 'Annette Hegg Dark Red'. J. Amer. Soc. Hort. Sci. 111:114-121.

Nell, T.A. 2003. Postharvest care and handling of flowering potted plants, p. 185-199. In: D. Hamrick (ed.). Ball redbook, vol. 2.17 ${ }^{\text {th }}$ ed. Ball Publ., Batavia, Ill.

Nowak, J. and R.M. Rudnicki. 1990. Postharvest handling and storage of cut flowers, florist greens, and potted plants. Timber Press, Portland, Ore.

Ohkawa, K., Y. Kasahara, and J.-N. Suh. 1999. Mobility and effects on vase life of silver-containing compounds in cut rose flowers. HortScience 34:112-113.

Sacalis, J.M. 1978. Ethylene evolution by petioles of sleeved poinsettia plants. HortScience 13:594-596.

Sacalis, J.N. 1993. Cut flowers: Prolonging freshness. $2^{\text {nd }}$ ed. Ball Publ., Batavia, Ill.

Saltveit, M.E. and R.A. Larson. 1981. Reducing leaf epinasty in mechanically stressed poinsettia cultivars. J. Amer. Soc. Hort. Sci. 106:156-159.

Saltveit, M.E. and R.A. Larson. 1983. Effect of mechanical stress and inhibitors of protein synthesis on leaf epinasty in mechanically stressed poinsettia plants. J. Amer. Soc. Hort. Sci. 108:253-257.

Saltveit, M.E., D.M. Pharr, and R.A. Larson. 1979. Mechanical stress induces ethylene production and epinasty in poinsettia cultivars. J. Amer. Soc. Hort. Sci. 104:452-455.

Serek, M., E.C. Sisler, and M.S. Reid. 1995. Effects of 1-MCP on the vase life and ethylene response of cut flowers. Plant Growth Regulat. 16:93-97.

Staby, G.L., J.F. Thompson, and A.M. Kofranek. 1978. Postharvest characteristics of poinsettias as influenced by handling and storage precedures. J. Amer. Soc. Hort. Sci. 103:712-715. 